

\title{
THE EFFECT OF AGRIBUSINESS SYSTEM IMPLEMENTATION TO DAIRY CATTLE FARMS PRODUCTIVITY IN SEMARANG REGENCY
}

\author{
Edy Prasetyo $^{1^{*}}$, Titik Ekowati $^{1}$, and Dian Wahyu Harjanti ${ }^{2}$ \\ 1)Agribusiness, Faculty of Animal and Agricultural Sciences, Universitas Diponegoro, Semarang, \\ Indonesia \\ 2)Animal Science, Faculty of Animal and Agricultural Sciences, Universitas Diponegoro, Semarang, \\ Indonesia \\ Correspondence email: edyprsty@yahoo.com
}

Submitted 14 February 2020; Accepted 12 August 2020

\begin{abstract}
ABSTRAK
Tujuan penelitian adalah: (i) mengetahui penerapan sistem agribisnis; (ii) mengetahui produktivitas susu sapi; dan (iii) menganalisis pengaruh penerapan sistem agribisnis terhadap produktivitas susu sapi pada peternakan sapi perah rakyat. Metode penelitian menggunakan metode survai dan sebagai unit elementer adalah peternak sapi perah rakyat. Penentuan sampel menggunakan Purposive Quota Sampling Method pada 69 responden. Data berupa data primer dan didukung data sekunder. Data dianalisis secara deskriptif kualitatif, deskriptif kuantitatif menggunakan analisis regresi linier berganda (multiple linear regression). Hasil penelitian menunjukkan, bahwa: (i) Penerapan sistem agribisnis dalam kategori baik dengan score 3,97; (ii) Skala usaha rata-rata 3,74 ekor/peternak dengan komposisi perbandingan sapi laktasi dengan sapi non laktasi $(42,25 \%: 57,75 \%)$, dan produktivitas susu sapi adalah 9,05 liter/ekor/hari; (iii) Secara serempak subsistem agribisnis berpengaruh nyata terhadap produktivitas susu sapi, sedangkan secara parsial subsistem praproduksi, subsistem akses jasa penunjang agribisnis, dan perencanaan agribisnis berpengaruh nyata terhadap produktivitas peternakan sapi perah rakyat, sedangkan subsistem tatalaksana usaha ternak tidak berpengaruh nyata.
\end{abstract}

Kata Kunci: produktivitas susu, sapi perah rakyat, sistem agribisnis

\begin{abstract}
The purposes of study were to examine the agribusiness system implementation of the dairy cattle farms; the average productions of dairy cattle and to analyse the effect of agribusiness system implementation on dairy cattle farm productivity. The study used survey methods and as elementary units were the dairy cattle farmers. The sample was determined by the Purposive quota sampling method towards 69 dairy cattle farmers. Data collected were primary and secondary data. Data were analysed using qualitative descriptive, quantitative descriptive, and inferencial statistic methods (multiple linear regression). The result showed that: (i) the agribusiness implementation system was in good category with score 3.97; (ii) the average business scale of dairy cattle farms was 3.74 head/farmer with composition of lactation dairy cattle and non-lactation dairy cattle was $42.25 \%$ and $57.75 \%$ respectively, and the milk productivity was 9.05 lt/head/day; (iii) Simultaneously, agribusiness subsystem was significant influenced to cow's milk productivity, while in partial term, the preproduction subsystem, agribusiness support access subsystem, and agribusiness planning were a significant effect on the productivity of dairy cattle farms, while the livestock business management subsystem was no significant effect.
\end{abstract}

Keywords: agribusiness system, dairy cattle farm, milk productivity 


\section{INTRODUCTION}

The development of animal husbandry sector aims to create an advanced, efficient, and resilient farm. A resilient farm means a condition where the available resources (capital, nature, labor, and technology) are utilized optimally to produce products that meet market demand regionally, nationally, as well as globally. Basically, animal husbandry development is directed to increase farmers' income and welfare, create employment and line of business, increase farmer's institutional contribution, and achieve a balance between the use and conservation of natural resources. The development steps taken include bringing the commodity aspects closer to the agribusiness system.

Saragih (2001) said that agricultural development with an agribusiness approach, especially livestock agribusiness, can increase the income of farmers and increase competitiveness. A livestock-based agribusiness system includes four subsystems, i.e. upstream agribusiness, on farm agribusiness, downstream agribusiness, and supporting institutions.

Semarang Regency is the center of cow milk production and the development of dairy in Central Java after Boyolali Regency. This is reflected in the number of dairy cattle population in 2017 of 25.557 cattles distributed across 15 districts in Semarang Regency, or $18,45 \%$ of the population in Central Java (Statistics Indonesia, 2018). In Semarang Regency, dairy cattle are raised in the smallholder farms with a scale of 1-6 cattles per farmer (Prasetyo et al., 2004).

The local autonomy that has been rolled out by the government in the reform era requires that potential dairy farms in Semarang Regency to have a maximum role, both for the interests of farmers and the region. In order to optimize this sector / commodity, the development which was initially focused on the technical approach (rearing) must be reformed by using an intensive management through agribusiness system approach. For this reason, comprehensive planning is needed, one of which can be realized through an analysis of agribusiness system implementation of dairy cattle farms in Semarang Regency.

The research objectives are to analyze (i) the agribusiness system implementation of the dairy cattle farms; (ii) the average productions of dairy cattle; (iii) and to analyze the influencing of agribusiness system implementation on dairy cattle farm productivity. While the results of the study are expected to be a contribution of thought in the decision making to determine strategies and development programs for agribusinessbased animal husbandry sub-sectors for the Regional Government and related Technical Agencies in Semarang Regency. Whereas an outcome of this study is the increasing efficiency of people's dairy cattle business, the increasing productivity and income of people's dairy farming in Semarang Regency.

\section{MATERIALS AND METHODS}

The study was conducted in July September 2017 in Semarang Regency by using survey method, while smallholder dairy farmers are standardized as elementary units. The sample determination was taken using Purposive Quota Non Sampling Method (Wirartha, 2006). Purposive was applied to determine the research location, namely in Getasan district as the most populated dairy cattle location in Semarang Regency. Quota was applied to determine the number of samples selected as elementary units, namely 69 respondents without calculating the total population as sampling frame.

Data were collected from primary and secondary sources. Primary data were collected through interviews based on questionnaires distributed to dairy cattle farmers as respondents, while secondary data as supporting unit of the study were collected from various relevant sources.

Data processing were conducted through tabulation and scoring, while data were analyzed using qualitative, quantitative descriptive, and multiple linear regression 
analyses. In order to identify the implementation of an agribusiness system, the descriptive analysis method was used based on surveys to the implementation of each agribusiness subsystem, including preproduction, livestock business management, agribusiness support institutions, and agribusiness planning. The unit used for identification is score and then classified using the Likkert scale concept based on excellent criteria (score 5), good (score 4), moderate (score 3), less (score 2), and poor (score 1). Whereas, milk productivity of dairy cattle cows were calculated based on the average production quantity per lactating dairy cow.

The effect of agribusiness systems implementation towards dairy cattle farms productivity was analyzed quantitatively by using Multiple Linear Regression Analysis, with mathematical formula as follows:

$$
\pi=\alpha+\beta_{1} X_{1}+\beta_{2} X_{2}+\beta_{3} X_{3}+\beta_{4} X_{4}+e
$$

\section{Information:}

$\pi \quad=$ Milk productivity of dairy cattle farmers (liters/cattle/year)

$\alpha \quad=$ Constant (intercept)

$\beta \mathrm{i}=$ Regression coefficients for each agribusiness subsystem

$\mathrm{X} 1=$ Implementation of preproduction subsystem (score)

$\mathrm{X} 2=$ Application of livestock business management subsystem (score)

$\mathrm{X} 3=$ Application of agribusiness support subsystem (score).

$\mathrm{X} 4=$ Application of agribusiness planning (score)

$\mathrm{e} \quad=$ Stochastic Deviation (disturbance terms)

Further, to test the regression equation, goodness of fit test is conducted, including F-test, t-test, and determination coefficient $\left(\mathrm{R}^{2}\right)$ (Ghozali, 2007).

\section{RESULTS AND DISCUSSION}

Based on Central Java Province Bureau of Statistics (2018), the population of dairy cows in Semarang Regency was 25.557 (18,45\% of total population in Central Java). The dairy cattle farms are widely cultivated in all districts (15 districts), where the top three populations are found in Getasan, Ungaran Barat, and Tengaran districts of 15,621, 1,830 and 1,618 cows, respectively. The dairy cattle farming from perpective of management of livestock business applied, most of which are still traditional. In the traditional pattern, economic principles have not been implemented optimally. On the other hand, the bargaining position and bargaining power of farmers are still relatively weak in their product marketing system. Generally in marketing their products, farmers are faced to intermediary traders and rarely meet directly with consumers (Prasetyo et al., 2004). This condition will result in an optimal productivity and small income obtained by farmers.

\section{Charactersitics of Dairy Cattle Farmers}

On average, dairy farmers are in their productive age. According to Law No. 13 of 2003 regarding Labor, people in productive age are those between $15-64$ years old. Productive age means that farmers are in their best conditions in terms of physical and thinking to do business activities, so this condition is a positive element for conducting business in animal husbandry sector. Farmers who are classified into productive ages reflect a good ability, knowledge, and skills in livestock business (Prasetyo et al., 2006).

Most farmers $(63.77 \%)$ are only graduated from elementary school, with an average experience of raising dairy cattle of 8.11 years. Education is a component of internal factors that greatly influence farmers in implementing a technology (Yusuf et al., 2006). Ekowati et al. (2014) mentioned that the level of education has an effect on new innovations created. According to Munthe et al., (2018), a low level of education generally will impede the introduction of a new innovation. On the other hand, the ability to operate the business in animal husbandry sector is often related to the length of 
experience of farmers in conducting their livestock business. However, in reality, there are many respondents who gain experience in raising livestock-from their parents or ancestors (from generation to generation). Almost all respondents work as farmers as their livelihoods (especially tobacco, vegetables, and food crop farmers). This condition reflects that dairy cattle business is mostly conducted by farmers in rural areas because farmers mostly live in rural areas. However, dairy cattle business for farmers is still largely considered as a side job. This condition, among others, is caused by the assumption that farming is more important than livestock business, in addition to other factors that may not be easily introduced by farmers (such as supplying food with ideal nutritional content, and marketing of products).

\section{The Implementation of Agribusiness Planning and System}

In order to identify the implementation of agribusiness subsystem, descriptive analysis was conducted based on the survey results on the implementation of each agribusiness subsystems, including preproduction, livestock business management, product handling and processing, product marketing, agribusiness support, and agribusiness planning (Prasetyo et al., 2012). In this analysis, the product handling and processing subsystems, as well as the marketing subsystem are not included as observational variables because theoretically to get cow's milk productivity, both subsystems are not needed. While the observation components in each agribusiness subsystems are vary from the numbers and variety. The observation component in the preproduction subsystem includes the availability of livestock production facilities, such as dairy cattle breed, forages, feed concentrates, medicines, labor, and business capital with 6 (six) appropriate aspects (right time, number, type, quality, product, and the right price). The observation component in the livestock farm management subsystem includes the selection of locations, livestock farm management, and farm continuity. The observation component in the agribusiness support service subsystem is based on its existence on the involvement of financial institutions, human resource development institutions, economic organization development, and research functions. While the observation component in agribusiness planning is based on its existence on market needs, the needs of downstream industries, agro-input networks, availability of business capital, competitive commodity selection, capital planning, and planning of labor requirements.

Based on the study results, it can be identified that the implementation of the agribusiness system (including preproduction subsystems, livestock business management, farmer access to agribusiness supporting institutions, and agribusiness planning) is in good category (average score of 3,97). Likewise when it is reviewed from the implementation of each agribusiness subsystem, where the overall category is in good condition, with an average score of 4,03 in the preproduction subsystem, 4.03 in the livestock business management subsystem, and 4,04 in agribusiness planning, except for farmer access to agribusiness supporting institutions which is in the medium to good category (score 3,52).

The low implementation of agribusiness subsystems in terms of access towards agribusiness support institutions, when compared to other subsystems (preproduction, livestock business management, and agribusiness planning) is due to farmers who are unable to utilize the existing agribusiness support institutions (mainly capital institution). This condition is indirectly caused by:

1 Lack of knowledge and understanding of farmers to access capital to financial institutions in Semarang Regency.

2 Lack of socialization in terms of procedures for accessing capital from financial institutions to farmers. 
This condition is consistent with Prasetyo et al. (2006), that factors that become obstacles for smallholder farmers in carrying out their livestock business activities are the availability of agribusiness support institutions, especially financial institutions and human resource development institutions, that have not been utilized properly by farmers. This condition is caused by the weak access of farmers.

Although the implementation of agribusiness systems, especially the procurement system for livestock production facilities, the livestock business management subsystem, agribusiness planning is in good condition, it does not mean that there are no problems faced by dairy cattle farmers. These problems include:

1 The price of dairy cattle whose in reality has not benefited dairy farmers.

2 The expensive price of feed concentrates and medicines for dairy cattle.

3 The marketing of fresh milk has not been able to be directed to a broad market segment, because most are still limited and concentrated in the Village Unit Cooperatives (KUD) as collecting traders.

\section{Productivity of Dairy Cattle Milk}

Based on the study results, it can be seen that the average scale of smallholder dairy farming is classified as small (3.74 heads/breeder), with the composition of lactated cattle $1.58 \quad(42.25 \%)$ and the remaining $57.75 \%$ are cows, bulls and calf. Milk productivity (average milk production) is 9.05 liters/head/day. This condition is seen that economically the dairy farms of the farmers are in the position of diseconomies of scale so that it will result in low business efficiency.

According to Sudono (1999), dairy cattle farming can generate profits if the number of lactating cows is greater than $60 \%$. Furthermore, the percentage of lactation cattle is a factor that cannot be ignored in a dairy farm as an effort to guarantee the farmer's income. These problems are partly caused by the low education level of smallholder farmers, resulting in a less optimal adoption of new innovations. According to Prasetyo et al. (2006), the level of education influences new innovations. The low productivity among smallholder dairy farmers is also thought to be caused by the low quality of feed given to livestock. The productivity level is also strongly influenced by the genetic potential of individuals among cattles, besides being caused by consumption and feed efficiency, as well as the age of cattle (Soeparno and Davies, 1987).

\section{The Influence of Agribusiness Systems on Productivity}

From the calculation using the SPSS program (Statistical Package for Social Sciences), there are obtained regression coefficient values, $t$ count, and error probability as shown in Table 1.

Based on Table 1, a regression equation can be formed as an estimator of the

Table 1. Estimation Result Model

\begin{tabular}{|c|c|c|c|c|c|c|}
\hline & \multirow[t]{2}{*}{ Model } & \multicolumn{2}{|c|}{$\begin{array}{c}\text { Unstandardized } \\
\text { Coefficients }\end{array}$} & \multirow{2}{*}{$\begin{array}{c}\text { Stand. Coef. } \\
\text { Beta }\end{array}$} & \multirow[t]{2}{*}{$\mathbf{T}$} & \multirow[t]{2}{*}{ Sig. } \\
\hline & & B & Std. Error & & & \\
\hline \multirow[t]{5}{*}{1} & Constant & -1831.07 & 1293.56 & & -1.42 & 0.162 \\
\hline & Preproduction (score) & 1035.41 & 419.76 & 0.348 & 2.47 & $0.016^{*}$ \\
\hline & On-farm (score) & 534.99 & 323.67 & 0.249 & 1.65 & 0.103 \\
\hline & Agroservices (score) & 576.03 & 190.70 & 0.407 & 3.02 & $0.004 *$ \\
\hline & $\begin{array}{l}\text { Agribusiness Planning } \\
\text { (score) }\end{array}$ & -796.24 & 260.39 & -0.507 & -3.06 & $0.003 *$ \\
\hline
\end{tabular}

Dependent Variable: Livestock's Weight Gain (kg).

Source: Processed Data, 2017 
influence of agribusiness subsystems towards the productivity of dairy cattle farms, as follows:

$$
\begin{aligned}
\mathrm{Y}= & -1831.07+1035.41 \mathrm{X}_{1}+534.99 \mathrm{X}_{2}+ \\
& 576.03 \mathrm{X}_{3}-796.24 \mathrm{X}_{4}
\end{aligned}
$$

The preproduction subsystem $\left(\mathrm{X}_{1}\right)$, livestock business management/on-farm $\left(\mathrm{X}_{2}\right)$, and agro services $\left(\mathrm{X}_{3}\right)$ have a positive correlation with the productivity of dairy cattle farming (Y). On the other hand, agribusiness planning $\left(\mathrm{X}_{4}\right)$ has a negative sign of correlation with the productivity of dairy cattle farming $(\mathrm{Y})$.

Based on the $F$ test, it is simultaneously reflected that the agribusiness subsystem's variables have a significant effect towards productivity of dairy cattle farming $(\mathrm{P} \leq 0.05)$. Based on the $t$ test, of the four independent variables, it turns out that only three independent variables have a significant effect on the dependent variable $(\mathrm{P} \leq 0.05)$, i.e. the preproduction subsystem $\left(\mathrm{X}_{1}\right)$, agribusiness support institutions subsystem $\left(\mathrm{X}_{3}\right)$, and agribusiness planning $\left(\mathrm{X}_{4}\right)$. While the livestock business management subsystem $\left(\mathrm{X}_{2}\right)$ has no significant effect $(\mathrm{P}>0,05)$ towards the productivity of dairy cattle farming (Y). The coefficient of determination is 0.248 , meaning that only $24.80 \%$ of the variable variation can explain the productivity of dairy cattle agribusiness. While another variable that can explain productivity is the condition of dairy cattle.

The preproduction subsystem has a significant influence towards livestock productivity. This condition implies that preproduction aspects at the level of dairy cattle farmers are still very responsive to fixes, especially the supply of dairy cattle breed, animal feed, and the provision of business capital. The success of livestock business is largely determined by the level of dairy cattle breeds's condition as the basic material. The real productivity of livestock is the result of genetic and environmental influences (Rianto and Purbowati, 2009). Hardjosubroto (1994) stated that genetic factors of livestock determine the ability possessed by a livestock, whereas environmental factors give an opportunity for livestock to show their abilities. The subsystem of agribusiness support services has a significant positive effect towards the productivity of dairy cattle farming. For this reason, activities related to access to agribusiness support services need to be better improved, especially access to product markets, business capital institutions, as well as training institutions for breeders and others. Agribusiness planning has a significant negative effect towards the productivity of dairy cattle farming. This condition is due to the fact that smallholder farmers do not respond well to aspects of agribusiness planning activities, or in other words, farmers are have not properly understood the importance of agribusiness planning. The livestock business management subsystem does not significantly affect the productivity of dairy cattle farming. This is based on the idea that the management of livestock farm is a routine activity for farmers so that aspects contained in it are not developed/given. In principle, farmer's response towards agribusiness planning and livestock farm management subsystems is a result of the low level of farmer's education. The level of education is very decisive in the realization of ideas and ease in absorbing technological innovations in agriculture and animal husbandry (Yusuf et al., 2006). Mukson et al. (2008) stated that in order to increase farmer's knowledge, it is necessary to have an informal additional education in the form of counseling or technical skills in animal husbandry that are directly needed by farmers.

\section{CONCLUSIONS}

The implementation of agribusiness systems, which include preproduction, livestock farm management, farmer access to agribusiness supporting institutions, and agribusiness planning is in good category (average score of 3.97). The average farm scale is 3.74 heads/breeder with composition of the ratio of lactating to non-lactating cows $(42.25 \%$ : $57.75 \%)$, and the average productivity of cow's milk is 9.05 liters/cow/day. Agribusiness subsystems that 
have a significant effect on the productivity of dairy cattle farming are preproduction, access to agribusiness support services, and agribusiness planning subsystems. Whereas the dairy farming business subsystem does not significantly affect the productivity of dairy cattle farming.

An intensive socialization of agribusiness systems and planning is needed along with its application for dairy cattle farmers. Motivation to encourage farmers is very needed, so that in operating their livestock business they do not consider it as a side job, but they always have a commercial orientation.

\section{REFERENCES}

Statistics Indonesia. 2018. Provinsi Jawa Tengah dalam angka (Jawa Tengan Province in figures) 2018. Semarang: Badan Pusat Statistik Provinsi Jawa Tengah.

Ekowati, T., D. Sumarjono, H. Setiyawan, and E. Prasetyo. 2014. Usahatani. Semarang: Undip Press.

Ghozali, I. 2007. Aplikasi analisis multivariate dengan program SPSS. Semarang: Undip Press.

Hardjosubroto, W. 1994. Aplikasi pemuliabiakan ternak di lapangan. Jakarta: PT. Gramedia Widiasarana Indonesia.

Mukson, S. Marzuki, P. I. Sari, and H. Setiyawan. 2008. Faktor-faktor yang mempengaruhi potensi pengembangan ternak sapi potong rakyat di Kecamatan Kaliori, Kabupaten Rembang, Jawa Tengah. J. Development of Tropical Ranch 33(4): 305-312.

Prasetyo, E., Sunarso, P. B. Santosa, and E. Rianto. 2012. The influence of agribusiness subsystem on beef cattle fattening farm's profit in Central Java. J. Indonesian Trop. Anim. Agric. 37(2): 121-126.

Prasetyo, E., S. Dwidjatmiko, W. Sumekar, T. Ekowati, and Mukson. 2004. Model of capital management and agribusiness management as efforts to develop people's livestock in Central Java. Competitive Research Report for Year I. Semarang: Faculty of Animal Husbandry, Diponegoro University.

Prasetyo, E., S. Dwidjatmiko, W. Sumekar, T. Ekowati, and Mukson. 2006. Model manajemen permodalan dan manajemen agribisnis sebagai upaya pengembangan peternakan rakyat di Jawa Tengah. Competitive Research Report for Year III. Semarang: Faculty of Animal Husbandry, Diponegoro University.

Rianto, E. and E. Purbowati, 2009. Panduan lengkap sapi potong. Jakarta: Penerbit Panebar Swadaya.

Saragih, B. 2001. Agribisnis (Paradigma baru pembangunan ekonomi berbasis pertanian). Jakarta: Pustaka Wirausaha Muda - PT. Loji Grafika Griya Sarana.

Sekretariat Negara Republik Indonesia. 2003. Undang-Undang Republik Indonesia Nomor 13 Tahun 2003 tentang Ketenagakerjaan. Sekretariat Negara Republik Indonesia, Jakarta.

Munthe, A., Siswoyo, and M. Fakhruddin. 2018. Sumber dan makna inovasi dalam pendidikan. POLYGLOT: A Journal of Language, Literature, Culture, and Education 11(4): 81-94.

Soeparno, and H. L. Davies. 1987. Studies on the growth and carcass composition in daldale wether lambs I: The effect of dietary energy concentration and pasture species. Aust. J. Agric. Res. 38: 403-415.

Wirartha, I. M. 2006. Metodologi penelitian sosial ekonomi. Yogyakarta: Penerbit CV Andi Offset.

Yusuf, B. D. Rosari, and J. Nulik. 2006. Studi adopsi teknologi penggemukan sapi potong di Kecamatan Amarasi Kabupaten Kupang NTT. Kupang: NTT Agricultural Technology Assessment Center. 